\title{
Correlation between HbA1c level and monocyte percentage in obesity
}

\author{
Edward Kurnia Setiawan Limijadi*, Meita Hendrianingtyas
}

\begin{abstract}
Background : HbAlc is one of the parameters that can be useful for diagnosing diabetes mellitus that can occur in obesity. Monocyte as an inflammatory cell is widely studied in relation to diabetes mellitus and obesity. The purpose of this study is to analyze the correlation between HbAlc levels and monocyte percentage in obesity.

Methods : A Cross-sectional study of 30 medical students at a private laboratory in Semarang on March-April 2017 was done. The monocyte percentage included incomplete blood count was examined with the Sysmex XS-800i hematology analyzer, while HbAlc level was examined with Hemocue HbAlc 501 System. Spearman test was done for analyzing data with $p<0.05$ was considered statistically significant.

Result and discussion : Median of HbAlc level was $5.8 \pm 0.23 \%$. Medians of leukocyte count, lymphocyte percentage, neutrophil percentage, and monocyte percentage were 8,600 $\pm 339,77 / \mu l$, lymphocyte percentage $33 \% \pm 1.19 \%$, neutrophil percentage $56 \% \pm 1.35 \%$, and monocyte percentage of $9.0 \% \pm 0.26 \%$, respectively. Spearman test showed that correlation value (r) was $0.131(p=0.489)$.

Conclusion and suggestion: There was no correlation between HbAlc levels and monocyte percentage in obesity. The increased of monocyte percentage can be used as monitoring and evaluation parameters in obesity that can lead to diabetes mellitus. Further study can be done in an obese population with older age as well as other parameters related to obesity and diabetes mellitus.
\end{abstract}

Keyword : HbAlc level; monocyte percentage; obesity

\section{INTRODUCTION}

Obesity is a condition with abnormal or excessive fat accumulation in the adipose tissue. ${ }^{1}$ Obesity occurs due to more calories entering the body through food than is used to support the body's energy. The accumulation of fat in the abdominal area is called central obesity or obesity android. ${ }^{2}$

In 2030, obesity is estimated to occur in $20 \%$ of the world population and $38 \%$ of the world population is overweight. Obesity in the United States reaches 30\% of the adult population. ${ }^{3}$ In the same idea, obesity in Indonesia has increased from 2013 to 2018 about 7\% reaching $21,8 \%$. Pekanbaru has high rates of obesity (63.4\%), especially central obesity. ${ }^{4}$ Obesity prevalence based on Basic Health Research Results (RISKESDAS) 2018, North Sulawesi province had the highest prevalence of obesity that is $30,2 \%$ and for the highest prevalence of central obesity was also occupied by North Sulawesi Province reaching 42,5\%..$^{5}$

Individuals with obesity will be susceptible to various diseases that appear chronically. Various organs will be affected by the condition of obesity. One of the abnormalities that can occur is the emergence of diabetes mellitus in addition to abnormalities that may appear in blood vessels in the form of blockage (atherosclerosis). The disorder occurs as a result of chronic inflammation in the body of obese individuals.

Inflammation occurs in obesity that affects the entire system of the body. Inflammation leads to an increase in proinflammatory cytokines that will determine the next process. Proinflammatory cytokines will make a disturbance in target organs related to the hormone insulin that plays a role in insulin resistance. The inflammatory process also results in disruption in fat tissue. Insulin resistance will lead to a condition of diabetes which will further increase HbA1c levels as one of the parameters in the diagnosis of diabetes mellitus. ${ }^{6}$

The inflammation that occurs will also activate the leucocyte cells as inflammatory cells, especially monocytes as chronic inflammatory cells. Monocytes play a role in stress-induced cells and induce an ongoing inflammatory response. Increased monocytes occur in these circumstances will aggravate the state of inflammation and increasingly affect the insulin resistance in obesity. ${ }^{7,8,9}$

The study by Onal et al and Lee et al suggest that HbA1c may be used as a marker in detecting insulin resistance or impaired glucose metabolism in obese children. ${ }^{10,11} \mathrm{HbA} 1 \mathrm{c}$ levels rise in obese adults both with diabetes and without diabetes mellitus as revealed by Emeribe et al. This suggests that HbAlc levels are important parameters used in evaluating obese individuals leading to diabetes mellitus. ${ }^{12}$

Research conducted by Breslin et al suggests that monocyte and inflammatory markers can be a marker for obese children at risk of developing in chronic diseases such as diabetes mellitus. ${ }^{13}$ There are various monocyte subpopulations associated with obesity. These subpopulations play a role in the development toward

Department of Clinical Pathology, Faculty of Medical, Universitas Diponegoro. Prof Soedarto, SH. Street, Tembalang, Semarang, Jawa Tengah 50275, Indonesia

* Corresponding author : E-mail: edwardksl@ fk.undip.ac.id 
chronic diseases as revealed by Devevre et al. ${ }^{14}$ Mattos et al described the same thing that monocytes play a role in the inflammatory process and the occurrence of advanced immune responses in obese children. ${ }^{15}$

Research on the relationship between $\mathrm{HbA} 1 \mathrm{c}$ and monocyte levels has not been done much, further related to obesity in young adulthood. This condition makes the need to do research on both parameters are related to obesity of young adult age.

\section{METHODS}

Descriptive analytic research with a crosssectional approach was conducted on 30 medical students of obesity in Medical Science student at Semarang. The study was conducted in March-April 2017. Samples were taken by accidental sampling by meeting inclusion and exclusion criteria. Inclusion criteria are 18-24 years old, healthy physical, IMT $\geq 27$ $\mathrm{kg} / \mathrm{m}^{2}$, and willing to follow the research. Exclusion criteria were respondents were pregnant, lipemic, and hemolysis sample.

The independent variable of this research was $\mathrm{HbA1c}$ level with scale ratio, and dependent variable was monocyte percentage with scale ratio. The percentage of monocytes included in the complete blood was examined with Sysmex XS-800i hematology analyzer, whereas HbA1c was examined using Hemocue HbA1c 501 System.

Data analysis was done by using the parametric test-Spearman test. Significance was expressed at $p$ $<0.05$. The research permission was obtained by ethical clearance from Medical Research Ethics Commission of Medicine Faculty of Diponegoro University.

\section{RESULTS}

Characteristics of this research subject can be seen in table 1 as follows:

Table 1. Characteristics of research subjects

\begin{tabular}{llll}
\hline Characteristics & N (\%) & Mean \pm SD & $\begin{array}{l}\text { Median } \\
\text { (Minimum- Maximum) }\end{array}$ \\
\hline Sex $\quad$ Male & $30(100 \%)$ & - & - \\
$\quad$ Female & $18(60 \%)$ & & $20(18-23)$ \\
Age (year) & $12(40 \%)$ & $20,30 \pm 1,418$ & $167,5(149-180)$ \\
Height $(\mathrm{cm})$ & - & $166,6 \pm 7,98$ & $90,20(63,1-118,6)$ \\
Weight $(\mathrm{kg})$ & - & $88,91 \pm 15,79$ & $31,20(27-38,7)$ \\
Body mass Index $\left(\mathrm{kg} / \mathrm{m}^{2}\right)$ & - & $31,85 \pm 3,77$ & \\
\hline
\end{tabular}

Table 1 shows that the subjects of the study with male sex are higher than female, that is 18 respondents (60\%) compared to 12 respondents (40\%). The average age of respondents is 20 years, with an age range of 18 to 23 years.

The calculation of Body Mass Index requires height and weight data. The height of the respondent has an average of $166.6 \pm 7.98 \mathrm{~cm}$, with a minimum height of $149 \mathrm{~cm}$ and a maximum of $180 \mathrm{~cm}$. The average weight of respondents is $88.91 \pm 15.79 \mathrm{~kg}$ with a minimum body weight of $63.1 \mathrm{~kg}$ and a maximum value of $118.6 \mathrm{~kg}$. Body mass index was calculated and got mean equal to $31,85 \pm 3,77 \mathrm{~kg} / \mathrm{m} 2$ with minimum value $27 \mathrm{~kg} / \mathrm{m}^{2}$ and maximum value $38,7 \mathrm{~kg} / \mathrm{m}^{2}$

A complete blood examination was performed to see the leukocyte profile obtained from the analytical tool examination can be seen in table 2 .
Table 2. Leukocyte profile of subjects

\begin{tabular}{ll}
\hline Variabel & Median \pm SE \\
\hline Leucocyte counte $(/ \mu \mathrm{l})$ & $8.600 \pm 339,77$ \\
Lymphocyte percentage $(\%)$ & $33 \pm 1,19$ \\
Neutrophil percentage $(\%)$ & $56 \pm 1,35$ \\
Monocyte percentage $(\%)$ & $9,0 \pm 0,26$ \\
\hline
\end{tabular}

Table 2 shows the leukocyte profile of subjects who were examined by using a hematologic analyzer. It appears that the number of leukocytes in the respondents is still within normal limits. The percentage of leukocyte cell types that has values exceeding the normal limit value was monocytes, while lymphocytes and neutrophils were still within normal limits. HbA1c examination with monocyte percentage and Spearman's test statistical analysis are presented in table 3 below. Spearman test analysis showed that there was no correlation between $\mathrm{HbA} 1 \mathrm{c}$ and monocyte percentage in the obesity respondent.

Table 3. Results of statistical analysis of HbA1c levels with monocyte percentage in obesity

\begin{tabular}{llll}
\hline Variabel & Median \pm SE & Correlation (r) & Significance $(\boldsymbol{p})$ \\
\hline HbA1c $(\%)$ & $5,8 \pm 0,23$ & 0,131 & \multirow{2}{*}{0,489} \\
Monocyte $(\%)$ & $9,0 \pm 0,26$ & & \\
\hline
\end{tabular}




\section{DISCUSSION}

This study took obese respondents from medical students. This study was taken with the reasons to see the association of obesity which has a risk of diabetes mellitus with the percentage of monocytes that are inflammatory cells play a role in the occurrence of diabetes mellitus in obese individuals. The results of the $\mathrm{HbAlc}$ examination on the majority of respondents were still below the reference value of less than $6.5 \%$, but there was one respondent who has high $\mathrm{HbAlc}$ levels more than the reference value. The percentage of monocytes examined has a higher value that is more than its reference value. More than $70 \%$ of respondents have this, so it can lead to a separate interpretation of chronic inflammation in the body of the obese individual.

The examination was also performed on the leukocyte profile of respondents in the form of leukocyte count, percentage of lymphocyte, and percentage of neutrophils. The entire result of the parameters has a value within the reference value (normal). This suggests that overall leukocytes are not yet activated for chronic inflammation that runs in the body of obese individuals, but the movement and the number of chronic inflammatory cells of the monocyte are already beginning to appear. This allows it to occur on an ongoing basis, and at some later date, at a more mature age can lead to a more severe or widespread inflammation, which can lead to diabetes mellitus. The next process will certainly lead to an increase in $\mathrm{HbAlc}$ levels in obese individuals in these circumstances. This situation will make the analysis of the relationship between the two variables becomes meaningful.

Other studies have much to say about $\mathrm{HbA1c}$ in obesity as well as monocyte levels in obesity. Research on the relationship between these two parameters on obesity is still not widely done. More research is done on conditions of certain diseases such as diabetes mellitus, coronary heart disease, stroke, and other related conditions. Research by Liu et al showed that $\mathrm{HbA} 1 \mathrm{c}$ and monocyte levels increased in obesity without diabetes mellitus with the achievement of meaning value. Both parameters can be part of an inflammatory marker in obese individuals. ${ }^{16}$

The same is also written by Kohut et al., which explained that there is a significant positive relationship between HbAlc and inflammatory markers and monocytes through monocyte chemokine examination. It suggests that monocytes are a parameter that responds to the contribution of type 2 diabetes mellitus in obese individuals. ${ }^{17}$

Inflammation with a classical process needs to be discussed in the state of the metabolic system, in this case, obesity, to explain the inflammatory processes that affect metabolic conditions and abnormalities that occur in cells and tissues. ${ }^{18,19}$ Obesity is a condition that is said to induce the occurrence of inflammation due to injury at body obesity. This condition spurred the occurrence of excessive oxidation (especially lipid oxidation) in cells. It follows that a continuous increase in the cycle leads to inflammation. ${ }^{20}$

Increased proinflammatory cytokines in these conditions will activate endothelium, leukocytes, and induce acute-phase proteins. Cells and tissues will experience stress that will experience cell death. The next effect that arises is the activation of macrophages, in this case, monocytes in response to cell stress and cell death. Activation of this monocyte will induce the subsequent inflammatory response so that the inflammatory process will continue. ${ }^{21,22}$

This inflammatory process disrupts to glucose metabolism in obese individuals. The occurrence of disorders of the vascular and functional abnormalities of fat cells or tissues can trigger and increase insulin resistance. The incidence of type 2 diabetes mellitus will increase with the occurrence of insulin resistance. $\mathrm{HbA1c}$ levels will increase with the occurrence of insulin resistance is getting worse. ${ }^{23,24,25}$

The study did not examine the parameters of inflammatory proteins and proinflammatory cytokines, which may increase with the increase of monocytes. This study did not directly measure insulin levels in respondents who could rule out abnormalities in the pancreas as insulin-forming organs. Further research is needed in the obese population with adult or older age without diabetes mellitus to see further relationship between the two variables in this study. Research on monocytes and biomolecular parameters associated with monocytes in inflammation or obesity needs to be done to find out further relationships, and research with other parameters is needed that develop with these obese populations.

\section{CONCLUSION}

There is no association between HBA1c and monocyte percentage in obesity. The increased monocyte count can be used as a monitoring and evaluation parameter in obesity that can develop in the direction of diabetes mellitus. Further research can be done on the obese population with older age as well as other parameters related to obesity and diabetes mellitus.

\section{REFERENCES}

1. World Health Organization. Obesity and overweight. WHO technical report series. Geneva.WHO; 2013.

2. Soegih R, Kunkun. Obesitas (permasalahan dan terapi praktis). Jakarta. Sagung Seto; 2009. 
3. Hruby A., Hu FB. The Epidemiology of obesity: A Big Picture. Pharmacoeconomics. 2015. 33(7): 673-89.

4. Sundari E., Masdar H., Rosdiana D. Angka Kejadian obesitas sentral pada masyarakat kota Pekanbaru. JOM FK. 2015. 2(2);1-16.

5. Badan Penelitian dan Pengembangan Kesehatan Departemen Kesehatan Republik Indonesia. Riset kesehatan dasar nasional 2018.

6. Jian PY. Mechanism of insulin resistance in obesity. Front Med. 2013. 7(1):14-24

7. Robert VC. Activated monocytes: yet another link between

systemic inflammation and obesity. J Clin Endocrinol Metab. 2014. 99(7):2347-9.

8. Gael B., Robert C., Bruno D, Corinne C, Violeta R., Marie P., et al. Impaired alternative macrophage differentiation of peripheral blood mononuclear cells from obese subjects. Diab Vasc Dis Res. 2015. 30:1-7.

9. Amano, SU, Cohen JL, Vangala P., Tencerova M., Nicoloro SM, et al. Local proliferation of macrophages contributes to obesity-associated adipose tissue inflammation. Cell Metabolism. 2014. 19:162-71.

10. Onal ZE, Atasayan V., Gurbiz T, Hepkaya E, Nuhoglu C. Association of glycosylated hemoglobin (HbA1c) levels with Iinsulin resistance in obese children. Afr Health Sci. 2014. 14(3): 5338.

11. Lee HS, Park HK, Hwang JS. HbA1c and glucose intolerance in obese children and adolescents. Diabet Med. 2012. 29(7):e102-5.

12. Emeribe AU, Elochukwu AC, Nasir1 IA, Bassey IE, Udoh EA. Clinical significance of glycated hemoglobin testing in obese subjects attending a tertiary hospital at Calabar, Nigeria. Sub-Saharan African Journal of Medicine. 2015. 2(3):134-41.

13. Breslin WL, Johnston CA, Strohacker K., Carpenter KC, Davidson TR, Moreno JP. Obese mexican american children have elevated MCP-1, TNF-a, monocyte concentration, and dyslipidemia. Pediatrics. 2015. 129(5):e1180-6.

14. Devêvre EF, Renovato-Martins M, Clément K, Sautès-Fridman C, Cremer I, Poitou C.Profiling of the three circulating monocyte subpopulations in human obesity. J Immunol. 2015. 194(8):3917-23.
15. Mattos RT, Medeiros NI, Menezes CA, Fares RCG, Franco EP, Dutra WO. Chronic low-grade inflammation in childhood obesity is associated with decreased IL-10 expression by monocyte subsets. PLoS ONE. 2016. 11(12): e0168610.

16. Liu S., Hempe JM, McCarter RJ, Li S, Foseca VA. Association between Inflammation and biological variation in Hemoglobin A1c in U.S. nondiabetic adults. J Clin Endocrinol Metab. 2015;100(6):236471.

17. Kohut M., Hallam J., Hodgkins S, Hurt T., Russell D., Lannginham-Foster L., et al. Association between immune response and the physiological and psychosocial factors that may predict development of type 2 diabetes in African American women. Brain, Behavior and Immunity. 2014;40:e52.

18. Medzhitov, R. Origin and physiological roles of inflammation. Nature. 2008:454(7203):428-35.

19. Un JJ., Myung SC., Obesity and its metabolic complications: the role of adipokines and the relationship between obesity, inflammation, insulin resistance, dyslipidemia and nonalcoholic fatty liver disease. Int J Mol Sci. 2014. 15(4): 6184-223.

20. Anna R., Jordi C., Carlos AV, Jorge J. Insulin resistance, inflammation, and obesity: role of monocyte chemoattractant protein-1 (or CCL2) in the Regulation of metabolism. Hindawi Publishing Corporation. 2010:1-11.

21. Henson, PM. dan Hume, HA. Apoptotic cell removal in development and tissue homeostasis. Trends in Immunology. 2006. 27(5):244-50.

22. Thomas AW, Kevin MV. Macrophages in tissue repair, regeneration, and fibrosis. Immunity. 2016. 44(3): 450-62.

23. Stephens M, Ludgate M, Rees DA. Brown fat and obesity: the next big thing? Clin Endocrinol (Oxf). 2011. 74:661-70.

24. Juonala M, Magnussen CG, Berenson GS, et al. Childhood adiposity, adult adiposity, and cardiovascular risk factors. N Engl J Med. 2011. 365:1876-85.

25. Shimizu I., Yoshida Y., Minamino T. Pathological role of adipose tissue dysfunction in cardiometabolic disorders. Int Heart J. 2015. 56(3):255-9. 